Brazilian Journal

of Chemical

Engineering

\title{
SYNTHESIS OF MORPHOLINE-BASED IONIC LIQUIDS FOR EXTRACTIVE DESULFURIZATION OF DIESEL FUEL
}

\author{
Renilma S. P. Fonseca ${ }^{1}$, Fernando C. Silva ${ }^{1}$, Francisco S. M. Sinfrônio ${ }^{2 *}$, \\ Caritas de J. S. Mendonça ${ }^{1}$ and Inocêncio S. dos S. Neto ${ }^{2}$ \\ ${ }^{1}$ Universidade Federal do Maranhão, Departamento de Química, São Luís, MA, Brasil. ORCID: 0000-0001-6777-6733; \\ ORCID: 0000-0001-6790-2541; ORCID: 0000-0002-9479-810X \\ ${ }^{2}$ Universidade Federal do Maranhão, Departamento de Engenharia Elétrica, São Luís, MA, Brasil. \\ E-mail: kjvida@mac.com - ORCID: 0000-0003-0388-7586; ORCID: 0000-0002-7667-1164
}

(Submitted: March 13, 2018 ; Revised: August 24, 2018 ; Accepted: November 9, 2018)

\begin{abstract}
Extractive desulfurization with ionic liquids has attracted significant attention from a growing number of scientists due to the current environmental restrictions on fuel. Protic ionic liquids (PILs) were synthesized via equimolar neutralization of morpholine and formic-based compounds. The obtained PILs were characterized by Fourier transform infrared and ${ }^{1} \mathrm{H}$ NMR spectroscopy and used as a promoter for the room temperature deep desulfurization of model oil and commercial B0S500 diesel. Extractive desulfurization of the model oil in n-octane showed that the alkyl chain length of the ionic liquid [Nmorph $]^{+}[\mathrm{HCOO}]^{-}$does not enhance the efficiency of dibenzothiophene (DBT) removal. Regardless, the [Morph $]^{+}[\mathrm{HCOO}]^{-} \mathrm{IL}$ is the most promising candidate for extractive desulfurization. The best results were obtained using multistage extraction $(\mathrm{n}=3)$ and a 1:1 volume ratio, resulting in a $99.44 \%$ removal rate of sulfur compounds. For commercial B0S500 diesel, extraction time significantly influenced the removal of sulfur species. For samples with multistage extraction and a 1:1 volume ratio, [Morph $]^{+}[\mathrm{HCOO}]^{-}$removed approximately $47.48 \%$ of the sulfur-containing compounds. The recycling study of [Morph $]^{+}\left[\mathrm{HCOO}^{-}\right.$suggests that the IL remains active for up to three operating cycles without losing efficiency. Keywords: Extractive desulfurization; Morpholine; Diesel; Ionic liquid.
\end{abstract}

\section{INTRODUCTION}

Recently implemented global environmental policies have caused a gradual reduction of harmful gas emissions, including $\mathrm{CO}_{x}, \mathrm{NO}_{x}$, and $\mathrm{SO}_{x}$, generated by burning fossil fuel. These policies have mitigated several negative environmental consequences such as photochemical smog and acid rain, and continue to safeguard public health worldwide by preventing cardiovascular diseases and deterioration of the nervous and immune systems (Balinge et al., 2016; Zhao et al., 2017).

Managing $\mathrm{SO}_{\mathrm{x}}$ emissions from the combustion of petroleum-based fuels has become increasingly important for both the automotive and petrochemical industries (Xu et al., 2017, Raj et al., 2017). It is important to consider the utility of several toxic sulfurbased fuel compounds that contribute to the lubricity of many commercial liquid fuels (Hazrat et al., 2015; Lapuerta et al., 2016).

In this context, hydrodesulfurization (HDS) processes are conventional industrial procedures for removing organosulfurized contaminants from fossil fuels by converting sulfur compounds into hydrogen sulfide $\left(\mathrm{H}_{2} \mathrm{~S}\right)$ and hydrocarbon derivatives (Yu et al., 2016). It is highly selective for the removal of thiols (mercaptans), sulfides, and disulfides, although it has limited extraction efficiency for heterocyclic sulfur and refractory compounds such as thiophene (TF), benzothiophene (BT), dibenzothiophene (DBT), and

\footnotetext{
* Corresponding author: Francisco S. M. Sinfrônio - E-mail: kjvida@mac.com
} 
other derivatives ( $\mathrm{Li}$ et al., 2015; Bui et al., 2017; Moghadam et al., 2017).

Unfortunately, HDS is costly since it requires industrial units operating at high temperatures $(>300$ ${ }^{\circ} \mathrm{C}$ ), pressure (3-10 MPa), and volume of hydrogen gas, with expensive catalysts and low energy efficiency (Kaisy, et al, 2016; Jiang et al., 2016; Zaid et al., 2017). Many of these limitations could be solved by developing desulfurization methods involving adsorption (Shah et al., 2016; Mirshra et al., 2017), oxidative desulphurization (Rezvani et al., 2017; Hitam et al., 2018), bio-desulfurization (Martínez et al., 2017; Paixão et al., 2016), microwave assisted desulphurization, ultrasound (Taheri-Shakib et al., 2017; Mozafari and Nasri, 2017), and extractive desulphurization (Safa et al., 2016; Elwan et al., 2017).

Extractive desulfurization (EDS) is a process where a solvent is placed in direct contact with the fuel to remove sulfur compounds by liquid-liquid extraction. Gentle operating conditions in the absence of hydrogen gas and low energy consumption can be inexpensively achieved with this method (Gao et al., 2015). However, EDS efficiency is strongly dependent on the solvent used and its chemical affinity with the sulfur-containing compounds (Ibrahim et al., 2017; Yang et al., 2016).

Thus, by definition EDS solvents must exhibit high chemical and thermal stability, non-toxicity, environmentally safety, and reusability. Because of these requirements, most conventional organic solvents used in liquid-liquid extractions cannot be applied in EDS (Li et al., 2017; Bhutto et al., 2016).

Ionic liquids (ILs), a novel class of green solvents, have recently attracted significant attention for their selective extraction of sulfur-containing compounds from diesel/gasoline (Liu et al., 2017, Julião et al., 2017).

ILs are molten salts with melting points below the boiling point of water due to their small lattice enthalpies and large entropy changes upon melting. ILs are often composed of an unsymmetrical organic cation and an inorganic complex anion, resulting in remarkable properties such as nonvolatility, thermal stability, nonexplosion, high polarity, and temperaturedependent miscibility with water (Jha et al., 2016, Ahmed et al., 2015). A wide variety of anions and cations can be incorporated into ILs, dramatically modifying their physical characteristics for specific applications.

IL-based solvents are often classified as either aprotic ionic liquids (AILs) or protic ionic liquids (PILs). In AILs the ions do not contain any transferable protons and PILs, also called Brønsted salts, are solvents obtained by proton transfer from a Brønsted acid to a Brønsted base (Vafaeezadeh and Alinezhad, 2016). It should be noted that PIL solvents often contain protons with higher mobility when compared to the other ILs.

This study aims to synthesize and characterize PILs containing the morpholine cation and to evaluate their efficiency for extractive desulphurization of model oil and commercial B0S500 diesel.

\section{EXPERIMENTAL}

\section{Materials}

The ILs were synthesized using analytical grade chemicals without further purification: formic acid (Sigma Aldrich, 99\%), morpholine (Morph, Sigma Aldrich, 99\%), N-methylmorpholine (Nmorph, Sigma Aldrich, 99\%), n-octane (Merck, 99\%), and dibenzothiophene (DBT, Acros Organics, 98\%). Commercial B0S500 diesel was purchased from Distribuidora de Combustível Granel Ltda., São Luís, Maranhão (Brazil).

\section{IL synthesis and characterization}

The $[\mathrm{Morph}]^{+}[\mathrm{HCOO}]^{-}$and $[\mathrm{Nmorph}]^{+}[\mathrm{HCOO}]^{-}$ ionic liquids were prepared according to the methods described by Brigouleix et al. (2010) via the proton transfer reaction between a Brønsted acid (formic acid) and morpholine (Fig. 1a) or N-methylmorpholine (Fig. $1 \mathrm{~b}$, Brønsted bases).

A three-necked round bottom flask immersed in an ice bath was connected to a reflux condenser, dropping funnel, and digital thermometer. Each Brønsted base was gently dropped into the formic acid, under constant stirring $(600 \mathrm{rpm})$ and temperature $\left(\approx 5.0^{\circ} \mathrm{C}\right)$. Subsequently, the reaction mixture was isothermally treated $\left(25.0^{\circ} \mathrm{C}\right)$ for an additional $4 \mathrm{~h}$ under constant stirring. The final product was then recovered and dried under vacuum $\left(12 \mathrm{~h}\right.$ at $\left.80^{\circ} \mathrm{C}\right)$ to remove residual water and/or trace reagents.

The obtained ILs were then characterized by Fourier transform infrared (FTIR) and ${ }^{1} \mathrm{H}$ NMR spectroscopy. FTIR spectroscopy was performed using an IR prestigie-21 infrared spectrometer (Shimadzu) with $\mathrm{KBr}$ as dispersant agent $(1: 100 \mathrm{wt} / \mathrm{wt})$ and a recording range between 400 and $1000 \mathrm{~cm}^{-1}$. Proton nuclear<smiles>CC(C)OC=O</smiles><smiles>CN1CCOCC1</smiles>

Figure 1. IL synthesis of (a) $[\mathrm{Morph}]^{+}\left[\mathrm{HCOO}^{-}\right.$and (b) $[\mathrm{Nmorph}]^{+}[\mathrm{HCOO}]^{-}$. 
magnetic resonance spectra were recorded using a 400 $\mathrm{MHz}$ Bruker DRX spectrometer (Bruker) using $\mathrm{CDCl}_{3}$ as solvent.

The kinematic viscosities were obtained according to the ASTM D445 Standard Test Method using a SCHOTT CT 52 viscometer with a Cannon-Fenske $520(75)$ calibrated glass capillary at $40{ }^{\circ} \mathrm{C}$. The water content was determined via Karl-Fischer titration (method TitroLine KF). The samples and solvent were dissolved in methanol and titrated in steps of 0.0025 $\mathrm{cm}^{3}$.

\section{Model oil preparation}

The model oil was prepared by dissolving $0.5 \mathrm{~g}$ of DBT in $1.0 \mathrm{~L}$ of n-octane, yielding a blend with 714 ppm sulfur.

\section{Extractive desulfurization of the model oil}

Two distinct mechanisms were evaluated for the desulfurization of the model oil: single and multiple stage. In the first case, desulfurization was performed in a $50 \mathrm{~mL}$ two-necked round bottom flask by mixing the model oil and each IL (volume ratio $=1: 1,1: 3$, or $1: 5)$ at room temperature $\left(25{ }^{\circ} \mathrm{C}\right.$ for $\left.30 \mathrm{~min}\right)$ under vigorous stirring. Conversely, multiple stage desulphurization was performed using the same apparatus and temperature, but three consecutive extractions were performed using volume ratios of 1:1 and 1:2. After 10 min of extraction (representing a single cycle), the immiscible phases were separated by decanting. Subsequently, a fresh aliquot of pure IL was added to the extracted model oil and a new extraction run was initiated.

The sulfur in the model oil layer, before and after desulfurization, was determined using highperformance liquid chromatography (HPLC, Shimadzu) with a UV-SPD20A detector at $280 \mathrm{~nm}$ using C18 (CLC - ODS M) $150 \mathrm{~mm} \times 4.6 \mathrm{~mm} 20$ $\mu \mathrm{m}$ columns. A column temperature of $25^{\circ} \mathrm{C}$, mobile phase of methanol:water $(90: 10 \mathrm{vol} / \mathrm{vol})$ and flow-rate of $1.0 \mathrm{~mL} \cdot \mathrm{min}^{-1}$ were used in the HPLC runs and each experiment was performed in triplicate.

Finally, sulfur extraction efficiency was estimated according Eq. (1) and the Nernst partition coefficient $\left(\mathrm{K}_{\mathrm{N}}\right)$ was predicted according to Eq. (2):

Sulfur removal $(\%)=\frac{\left(\mathrm{S}_{0}-\mathrm{S}_{\mathrm{f}}\right)}{\mathrm{S}_{0}} \times 100$

$\mathrm{K}_{\mathrm{N}}=\frac{\text { Sulfur concentration }_{\mathrm{IL}}}{\text { Sulfur concentration }_{\text {model oil }}}$

where, $\mathrm{S}_{0}(\mathrm{ppm})$ is the initial sulfur concentration and $S_{f}(p p m)$ is the sulfur concentration after extraction.

\section{Extractive desulfurization of the commercial B0S500 diesel}

Desulfurization extraction of the commercial B0S500 sample was performed using volume ratios of 1:1 and 1:3 and extraction times of 30 and $60 \mathrm{~min}$ in both single and multiple stages. Sulfur in the diesel, before and after desulfurization, was evaluated using a wavelength dispersive X-ray fluorescence (WDXRF) spectrometer (S8 Tiger, Bruker), with a rhodium tube operating at $20 \mathrm{~kW} / 50 \mathrm{~mA}$. The PETRO QUANT ${ }^{\circledR}$ calibration method was performed with XS - 55 detection crystals, $0.46^{\circ}$ collimator, helium gas purge, and Prolene ${ }^{\circledR}(3.6 \mu \mathrm{m})$ film with a container and sample mask of $0.34 \mathrm{~mm}$.

\section{Regeneration of the IL}

The $[\mathrm{Morph}]^{+}\left[\mathrm{HCOO}^{-}\right.$IL was regenerated by re-extraction with low-boiling hydrocarbons as previously reported by Gao et al. (2009). The IL was re-extracted twice with hexane (ionic liquid/solvent ratio $=1: 1$ ) for $30 \mathrm{~min}$ (Figure 2). Subsequently, the IL was heated to $80^{\circ} \mathrm{C}$ for $2 \mathrm{~h}$ to remove hexane traces and was then used in a new extraction cycle.

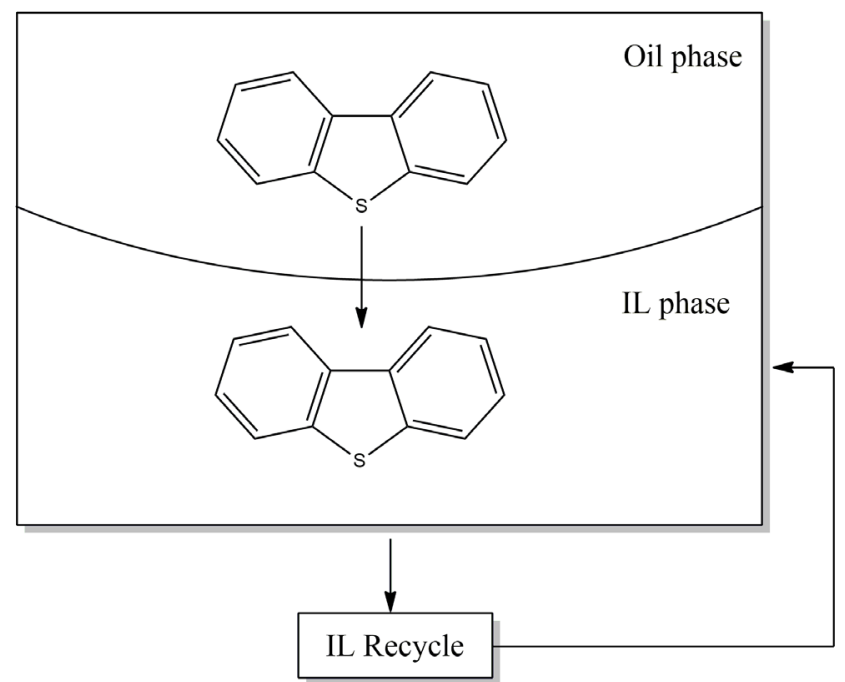

Figure 2. Extractive desulfurization mechanism using IL solvents.

\section{RESULTS AND DISCUSSION}

\section{Characterization of the ILs}

FTIR spectroscopy

The structures of the $[\mathrm{Morph}]^{+}[\mathrm{HCOO}]^{-}$and $[\mathrm{Nmorph}]^{+}[\mathrm{HCOO}]^{-}$ILs were investigated by FTIR spectroscopy (Figure 3). The infrared active modes for the cation species were detected at approximately 1442 and $1648 \mathrm{~cm}^{-1}$ and were assigned as $v(\mathrm{C}-\mathrm{N})$ stretching modes. The $v(\mathrm{C}-\mathrm{H})_{\mathrm{sat}}$ and $v(\mathrm{~N}-\mathrm{H})$ stretching modes were observed at 2985-2863 and $1457 \mathrm{~cm}^{-1}$, respectively, as previously reported by Ren et al. (2014). The vibration modes at 1372 and $1283 \mathrm{~cm}^{-1}$ 


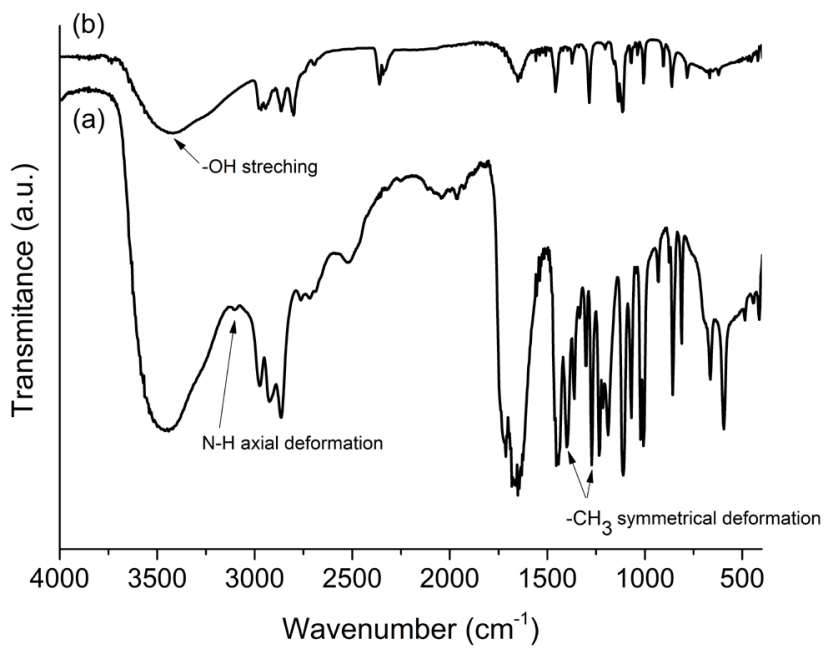

Figure 3. FTIR spectra of (a) $[\mathrm{Morph}]^{+}[\mathrm{HCOO}]^{-}$and (b) $[\mathrm{Nmorph}]^{+}[\mathrm{HCOO}]^{-}$ILs.

can be attributed to symmetrical deformations of $-\mathrm{CH}_{3}$ groups. The stretching modes of the $v(\mathrm{O}-\mathrm{H})$ groups were detected at $3457 \mathrm{~cm}^{-1}$ (Kahani et al., 2017; Dharaskar et al., 2016). For the [Morph $]^{+}[\mathrm{HCOO}]^{-}$ sample, the vibration mode detected at $3097 \mathrm{~cm}^{-1}$ was attributed to $\delta(\mathrm{N}-\mathrm{H})$ axial deformation of the amine groups.

\section{${ }^{1} H$ NMR analysis}

The ${ }^{1} \mathrm{H}$ NMR spectra for both [Morph $]^{+}[\mathrm{HCOO}]$ and $[\mathrm{Nmorph}]^{+}[\mathrm{HCOO}]^{-}$ILs are shown in Figure 4. The chemical shifts (multiplicity, integration) were as follows for $[\mathrm{Morph}]]^{+}[\mathrm{HCOO}]^{-}{ }^{1} \mathrm{H}$ NMR $\left(400 \mathrm{MHz}, \mathrm{CDCl}_{3}\right): \delta(\mathrm{ppm})=3.70(\mathrm{t}, 4 \mathrm{H},(1)), 3.66$ $(\mathrm{t}, 4 \mathrm{H},(2)), 8.04(\mathrm{~s}, 2 \mathrm{H},(3))$, and $8.06(\mathrm{~s}, 1 \mathrm{H},(4))$. $[\mathrm{Nmorph}]^{+}[\mathrm{HCOO}]^{-1} \mathrm{H}$ NMR $\left(400 \mathrm{MHz}, \mathrm{CDCl}_{3}\right): \delta$ $(\mathrm{ppm})=3.91(\mathrm{t}, 4 \mathrm{H},(1)), 2.99(\mathrm{t}, 4 \mathrm{H},(2)), 6.41(\mathrm{~s}, 2 \mathrm{H}$, (3)), $8.30(\mathrm{~s}, 1 \mathrm{H},(4))$, and $2.65(\mathrm{~s}, 3 \mathrm{H},(5))$. According to the ${ }^{1} \mathrm{H}$ NMR data, the purities of [Morph $]^{+}[\mathrm{HCOO}]$ and $[\mathrm{Nmorph}]^{+}[\mathrm{HCOO}]^{-}$ionic liquids were $95.5 \%$ and $96.8 \%$, respectively and the water content was estimated to be $61 \mathrm{ppm}$.

\section{Desulfurization of the model oil}

Operating parameters such as the extracted and extractor ratio, time of extraction, and extraction cycles can dramatically influence the extraction efficiency in desulfurization. Thus, these factors were evaluated during the extractive desulfurization of both model oil and commercial B0S500 diesel.

Effect of the $\left(\mathrm{V}_{\mathrm{IL}} / \mathrm{V}_{\text {model oil }}\right)$ ratio on the extractive desulfurization

To enhance the extractive desulfurization efficiency, the ratio of the extracted component and extractor agent was empirically optimized under the following experimental conditions: model oil (714 ppm sulfur); volume ratios $\left(\mathrm{V}_{\mathrm{IL}} / \mathrm{V}_{\text {model oil }}\right)$ of $1: 5,1: 3$, and $1: 1$; and 25 ${ }^{\circ} \mathrm{C}$. Figure 5 shows the influence of the $\left(\mathrm{V}_{\mathrm{IL}} / \mathrm{V}_{\text {model oil }}\right)$

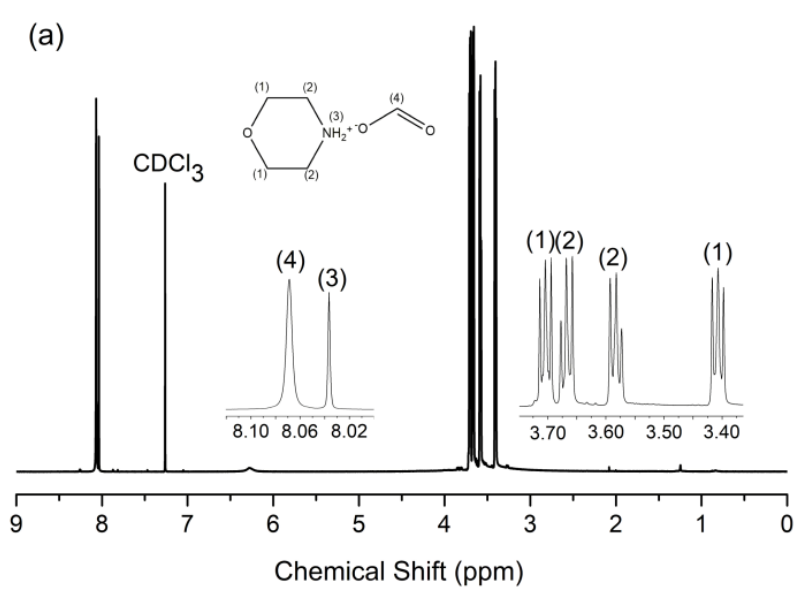

(b)

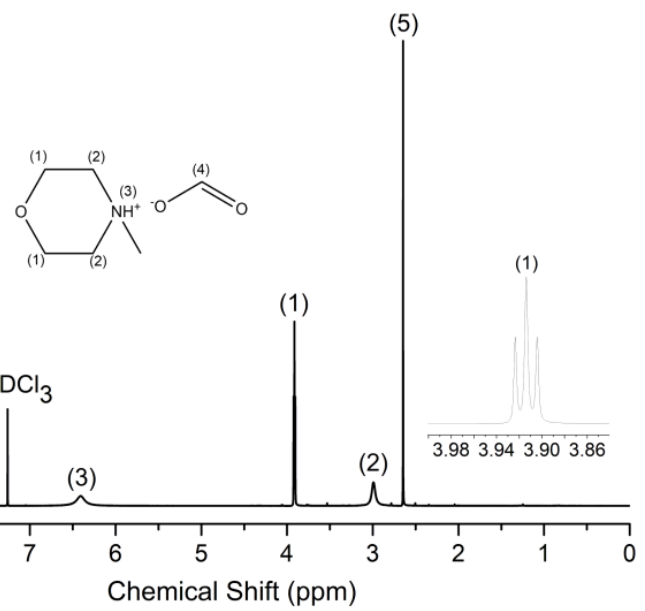

Figure 4. ${ }^{1} \mathrm{H}$ NMR spectra of (a) $[\mathrm{Morph}]^{+}[\mathrm{HCOO}]^{-}$ and (b) $[\mathrm{Nmorph}]^{+}[\mathrm{HCOO}]^{-}$ILs $\left(25^{\circ} \mathrm{C}\right.$ in $\left.\mathrm{CDCl}_{3}\right)$.

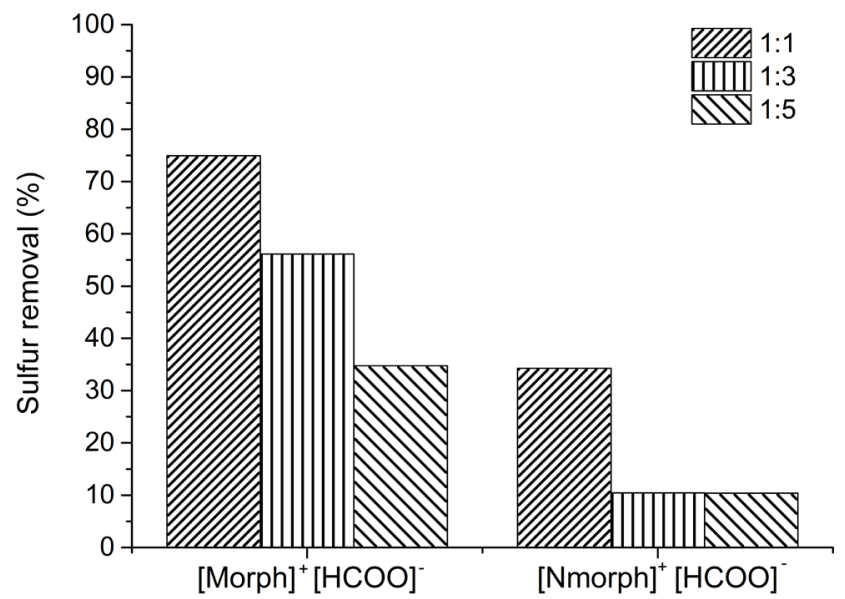

Figure 5. Sulfur removal as function of the volume ratio of model oil to IL.

ratio on the extractive desulfurization of DBT in model oil for a single stage extraction with both ILs.

According to Figure 5, the extraction efficiency increased with higher IL concentration in the system. Greater sulfur removal was achieved when an $\left(\mathrm{V}_{\mathrm{II}} /\right.$ $\left.\mathrm{V}_{\text {model oil }}\right)=1: 1$ was applied under single extraction conditions (Table 1). 
Table 1. Desulfurization of the model oil with different ILs.

\begin{tabular}{cccc}
\hline ILs & IL/model oil & $\begin{array}{c}\text { S-removal Final S-content } \\
\text { (\%) }\end{array}$ & \begin{tabular}{c} 
(ppm) \\
\hline
\end{tabular} \\
\hline \multirow{2}{*}{ IMorph $^{+}[\mathrm{HCOO}]^{-}$} & $1: 1$ & 75 & 179 \\
& $1: 3$ & 56 & 313 \\
& $1: 5$ & 35 & 466 \\
[Nmorph $^{+}\left[\mathrm{HCOO}^{-}\right.$ & $1: 1$ & 34 & 640 \\
& $1: 3$ & 11 & 639 \\
& $1: 5$ & 10 & 469 \\
\hline
\end{tabular}

Temperature $=25{ }^{\circ} \mathrm{C}$, extraction time $=30 \mathrm{~min}$ and initial sulfur concentration of model oil $=714 \mathrm{ppm}$.

Sulfur compounds with aromatic rings (i.e., BT, DBT, and their derivatives) often reduce $\pi-\pi$ interaction (aromatic ring current effect) and enhance $\mathrm{CH}-\pi$ bond interactions and hydrogen bonding effects due to electrophilic attack (Yuan et al., 2016, Anatharaj et al., 2011). In addition, according to Domańska e Wlazio (2014), the extraction efficiency of non-aromatic cation morpholinium-based ILs is significantly influenced by hydrogen bonding of the hetero-atoms of sulfur compounds with the IL cation. In addition, the kinetics are significantly affected by the specific volume and shape of the IL (Zhao et al., 2016).

Although the [Nmorph $]^{+}[\mathrm{HCOO}]^{-}$IL has a longer alkyl group attached to the cation chain compared to $[\mathrm{Morph}]^{+}[\mathrm{HCOO}]^{-}$, the replacement of the methyl group does not reduce its desulfurization efficiency for the model oil. Similar behavior was reported for a pyridinium-based IL (Rodríguez-Cabo et al., 2014). These results are supported by the lower $[\mathrm{Nmorph}]^{+}[\mathrm{HCOO}]^{-}$sulfur partition coefficient $\left(\mathrm{K}_{\mathrm{N}}\right.$, Table 2).

Furthermore, the lower efficiency of $[\mathrm{Nmorph}]^{+}[\mathrm{HCOO}]^{-}$may be related to its higher viscosity, which may cause a reduction in the mass transfer potential and consequently lower extraction capacity (Zhang et al., 2017; Mafi et al., 2018) (Table $3)$.

Table 2. Sulfur partition coefficients $\left(K_{N}\right)$ of the ILs at different volume ratios of IL to model oil.

\begin{tabular}{|c|c|c|c|}
\hline \multirow{2}{*}{ ILs } & \multicolumn{3}{|c|}{$\mathrm{K}_{\mathrm{N}}\left[\mathrm{mg}(\mathrm{S}) \mathrm{kg}(\mathrm{IL})^{-1 / 1} / \mathrm{mg}(\mathrm{S}) \mathrm{kg}(\mathrm{oill})^{-1}\right]$} \\
\hline & $1: 1$ & $1: 3$ & $1: 5$ \\
\hline$[\mathrm{Morph}]^{+}[\mathrm{HCOO}]^{-}$ & 2.99 & 1.28 & 0.53 \\
\hline$[\mathrm{Nmorph}]^{+}[\mathrm{HCOO}]^{-}$ & 0.52 & 0.12 & 0.16 \\
\hline
\end{tabular}

Table 3. Viscosities of the ILs at $25^{\circ} \mathrm{C}$.

\begin{tabular}{cc}
\hline ILs & $\begin{array}{l}\text { Viscosity } \\
\left(\mathbf{m m}^{2} \mathbf{. s}^{-1}\right)\end{array}$ \\
\hline$[\mathrm{Morph}]^{+}[\mathrm{HCOO}]^{-}$ & 8.69 \\
{$[\mathrm{Nmorph}]^{+}[\mathrm{HCOO}]^{-}$} & 13.30 \\
\hline
\end{tabular}

\section{Multiple stage desulfurization}

Although single extraction desulfurization provided good sulfur removal, the final concentration of sulfur in the model oil did not meet the Brazilian
Control Agency (ANP) standards of 10 and 50 ppm of sulfur for light- and heavy-weight vehicles, respectively. Thus, multistage extraction (three cycle) was performed (Table 4).

The HPLC data (Figure 6) show that, after three consecutive extraction cycles, the concentration of sulfur compounds in the model oil was reduced from 714 to $4 \mathrm{ppm}$, (representing a $99.44 \%$ removal rate) and $114 \mathrm{ppm}(84.03 \% \text { removal) for the [Morph }]^{+}[\mathrm{HCOO}]^{-}$ and $[\mathrm{Nmorph}]^{+}[\mathrm{HCOO}]^{-}$ILs, respectively. These results were confirmed by WDXRF spectroscopy, which showed that the multistage extractive desulfurization of DBT with [Morph $]^{+}[\mathrm{HCOO}]^{-}$achieved $99.99 \%$ sulfur removal.

Table 4. Multistage extraction performance for the model oil with different volume ratios of IL to model oil.

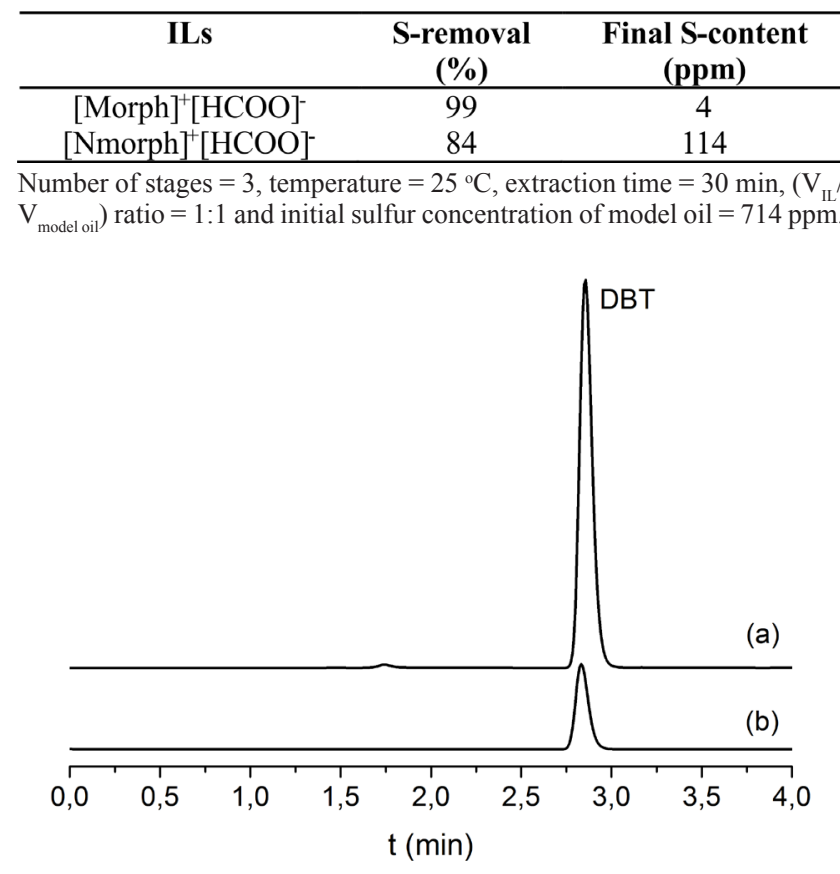

Figure 6. HPLC chromatograms of the model oil (a) before and (b) after extraction.

\section{Desulfurization of commercial B0S500 diesel Effect of time on sulfur removal}

Several time-based desulfurization studies have been reported based on the desulfurization of commercial products since their chemical compositions are complex and extraction is significantly influenced by type of sulfur-based contaminants. In this context, the implications of kinetics on sulfur removal efficiency were investigated at two time intervals with different volume ratios and extraction types (Table 5).

As shown in Table 5, with longer extraction times and higher $\left(\mathrm{V}_{\mathrm{IL}} / \mathrm{V}_{\text {commercial BoS500 }}\right)$ ratios, extraction of sulfur compounds from the fuel media increased, indicating more significant molecular interactions between the target compounds and ILs. However, it 
Table 5. Desulfurization of diesel using $[\mathrm{Morph}]^{+}[\mathrm{HCOO}]^{-} \mathrm{IL}$ at different times and with different $\left(\mathrm{V}_{\mathrm{IL}} / \mathrm{V}_{\text {commercial Bos500 }}\right)$ ratios.

\begin{tabular}{ccccc}
\hline Extraction & $\begin{array}{c}\text { Time } \\
\text { (min) }\end{array}$ & $\begin{array}{c}\text { Volume } \\
\text { ratio }\end{array}$ & $\begin{array}{c}\text { S-removal } \\
(\%)\end{array}$ & $\begin{array}{c}\text { Final S-content } \\
\text { (ppm) }\end{array}$ \\
\hline \multirow{3}{*}{ Single } & \multirow{2}{*}{30} & $1: 1$ & 23 & 350 \\
& & $1: 3$ & 14 & 393 \\
& \multirow{2}{*}{60} & $1: 1$ & 35 & 304 \\
Multistage & \multirow{2}{*}{30} & $1: 3$ & 18 & 376 \\
& & $1: 1$ & 39 & 279 \\
& \multirow{2}{*}{60} & $1: 3$ & 23 & 354 \\
& & $1: 3$ & 47 & 240 \\
\end{tabular}

Temperature $=25^{\circ} \mathrm{C}$ and initial sulfur concentration of diesel $=500 \mathrm{ppm}$.

should be noted that, in all cases, the final S-content was still higher than the recommended levels, which was attributed to another DBT species in the real diesel media. Analogous results were previously reported by Daraskar et al. (2014), Gao et al. (2009), and Daraskar et al. (2015) with other ILs and multiple extraction processes.

\section{Regeneration}

In industrial processes, large volumes of ILs would be required for extraction desulfurization (Ren et al., 2015). Thus, several regeneration mechanisms have been proposed in the literature (Gao, et al., 2015) and mainly concern the precipitation of sulfur compounds by dilution in water or re-extraction with hydrocarbon solvents. However, when such methods were applied for complex blends, such as commercial diesel/ biodiesel, the amount of sulfur compounds retained in the IL was negligible due to dibenzothiophene deactivation mechanisms. Fortunately, some of these limitations can be overcome by re-extraction with low boiling point hydrocarbon solvents such as pentane or hexane (Eßer et al., 2014). Thus, in this study,

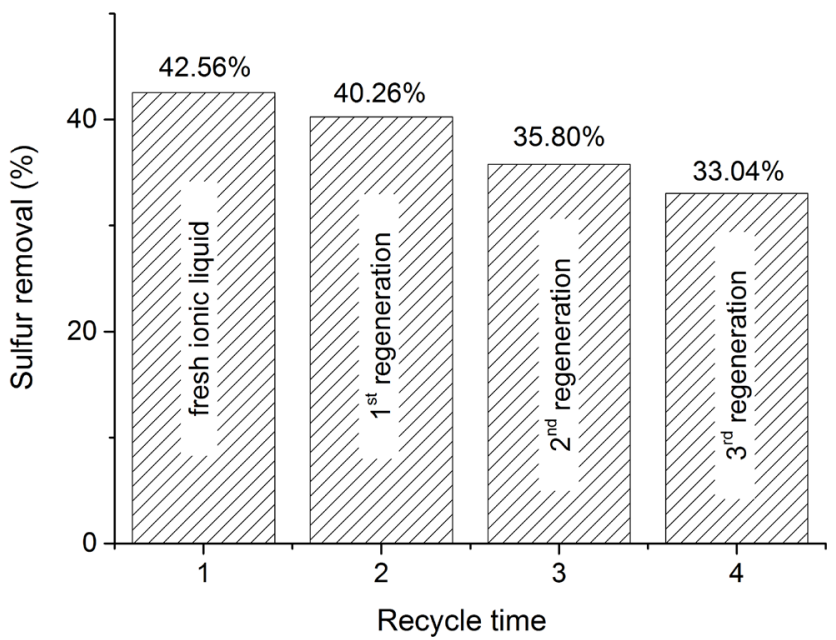

Figure 7. Desulfurization efficiency using the recovered $[\mathrm{Morph}]^{+}[\mathrm{HCOO}]^{-} \mathrm{IL}$ at $\left(\mathrm{V}_{\mathrm{IL}} / \mathrm{V}_{\text {commercial Bos500 }}\right)$ $=1: 1,25^{\circ} \mathrm{C}$, and $30 \mathrm{~min}$.
$[\mathrm{Morph}]^{+}[\mathrm{HCOO}]^{-}$was recovered with hexane and its desulfurization efficiency is shown in Figure 7.

As expected, a linear reduction of the desulfurization efficiency was observed with increasing number of cycles as after each stage of the recycling process, some sulfur compounds remained in the IL. However, the $[\mathrm{Morph}]^{+}[\mathrm{HCOO}]^{-}$IL remained sufficiently active after three recycling cycles.

\section{CONCLUSIONS}

$[\mathrm{Morph}]^{+}[\mathrm{HCOO}]^{-}$and $[\mathrm{Nmorph}]^{+}[\mathrm{HCOO}]^{-}$ILs were used as solvents in the extractive desulfurization of model oil and commercial B0S500 diesel via single and multiple cycle extractions. The [Morph $]^{+}[\mathrm{HCOO}]^{-}$ IL exhibited high extractive ability for DBT removal in single and multistage extractions with $\left(\mathrm{V}_{\mathrm{IL}} / \mathrm{V}_{\text {model oi }}\right)$ $=1: 1$ and an extraction time of $30 \mathrm{~min}$. The highest $\mathrm{K}_{\mathrm{N}}$ value of DBT desulfurization at a volume ratio of 1:1 also indicated that high dosages of ILs are required to achieve optimal desulfurization efficiency. For commercial B0S500 diesel, the removal efficiency of the sulfur compounds was influenced by the extraction time and the type of extraction used in the EDS. Thus, the best results were archived after three multistage extractions $(60 \mathrm{~min})$. The recycling study indicated that the $[\mathrm{Morph}]^{+}[\mathrm{HCOO}]^{-}$IL remained sufficiently active for extractive desulphurization after three consecutive cycles.

\section{ACKNOWLEDGMENT}

The authors thank the financial support of the Brazilian funding agencies: CAPES (Coordenação de Aperfeiçoamento de Pessoal de Nível Superior), CNPq (Conselho Nacional de Desenvolvimento Científico e Tecnológico) and FAPEMA (Fundação de Amparo à Pesquisa do Estado do Maranhão).

\section{REFERENCES}

Ahmed, O. U., Mjalli, F. S., Gujarathi, A. M., AlWahaibi, T., Al-Wahaibi, Y., AlNashef, I. M. Feasibility of phosphonium-based ionic liquids as solvents for extractive desulfurization of liquid fuels. Fluid Phase Equilibria, 401, 102-109 (2015). https://doi.org/10.1016/j.fluid.2015.05.015

Anantharaj, R., Banerjee, T. COSMO - RS based predictions for the desulphurization of diesel oil using ionic liquids: Effect of cation and anion combination. Fuel Processing Technology, 92, 39-52 (2011). https://doi.org/10.1016/j. fuproc.2010.08.018

Balinge, K. R., Khiratkar, A. G., Krishnamurthy, M., Patle, D. S., Cheralathan, K. K., Bhagat, R. Deep- desulfurization of the petroleum diesel using 
the heterogeneous carboxyl functionalized polyionic liquid. Resource - Efficient Technologies, 2, S105-S113 (2016). https://doi.org/10.1016/j. reffit.2016.10.005

Bhutto, A. W., Abro, R., Gao, S., Abbas, T., Chen, X., Yu, G. Oxidative desulfurization of fuel oils using ionic liquids: A review. Journal of the Taiwan Institute of Chemical Engineers, 62, 84-97 (2016). https://doi.org/10.1016/j.jtice.2016.01.014

Brigouleix, C., Anouti, M., Jacquemin, J., CaillonCaravanier, M., Galiano, H., Lemordant, D. Physicochemical characterization of morfolinium cation based protic ionic liquids used as electrolytes. The Journal of Physical Chemistry B, 114, 17571766 (2010). https://doi.org/10.1021/jp906917v

Bui, T. T., Nguyen, D. D., Ho, S. V., Nguyen, B. T., Uong, H. T. N. Synthesis, characterization and application of some non-halogen ionic liquids as green solvents for deep desulfurization of diesel oil. Fuel, 191, 54-61, (2017). https://doi.org/10.1016/j. fuel.2016.11.044

Dharaskar, S. A., Wasewar, K. L., Varma, M. N., Shende, D. Z., Tadi, K. K., Yoo, C. K. Synthesis, characterization, and application of novel trihexyl tetradecylphosphonium bis- (2,4,4-trimethylpentyl) phosphinate for extractive desulfurization of liquid fuel. Fuel Processing Technology, 123, 1-10 (2014). https://doi.org/10.1016/j.fuproc.2014.02.001

Dharaskar, S. A., Wasewar, K. L., Varma, M. N., Shende, D. Z., Yoo, C. Synthesis, characterization and application of 1-butyl-3-methylimidazolium tetrafluoroborate for extractive desulfurization of liquid fuel. Arabian Journal of Chemistry, 9, 578-587 (2016). https://doi.org/10.1016/j. arabjc.2013.09.034

Dharaskar, S., Wasewar, K. L., Varmas, M. N., Shende, D. Z. Imidazolium ionic liquid as energy eficiente solvente for desulfurization of liquid fuel. Separation and Purification Technology, 155, 101-109 (2015). https://doi.org/10.1016/j. seppur.2015.05.032

Domańska, U., Wlazlo, M. Effect of the cation and anion of the ionic liquid on desulfurization of model fuels. Fuel, 134, 114-125 (2014). https://doi. org/10.1016/j.fuel.2014.05.048

Elwan, H. A., Zaky, M. T., Farag, A. S., Soliman, F. S., Hassan, M. E. D. A coupled extractive-oxidative process for desulfurization of gasoline and diesel fuels using a bifuncional ionic liquid. Journal of Molecular Liquids, 248, 549-555 (2017). https:// doi.org/10.1016/j.molliq.2017.10.077

Eßer, J., Wasserscheid, P., Jess, A. Deep desulfurization of oil refinery streams by extraction with ionic liquids. Green Chemistry, 6, 316-322 (2004). https://doi.org/10.1039/B407028C
Gabrić, B., Sander, A., Bubalo, M. C., Macut, D. Extraction of S- and N-Compounds from the mixture of hydrocarbons by ionic liquids as selective solvents. The Scientific World Journal, 2013, 1-11 (2013). https://doi.org/10.1155/2013/512953

Gao, H., Xing, J., Li, Y., Li, W., Liu, Q., Liu, H. Desulfurization of diesel fuel by extraction with Lewis-Acidic Ionic Liquid. Separation Science and Technology, 44, 971-982 (2009). https://doi. org/10.1080/01496390802691232

Gao, H., Zeng, S. Z., Liu, X., Nie, Y., Zhang, X., Zhang, S. Extractive desulfurization of fuel using N-butylpyridinium-based ionic liquids. RSC Advances, 5, 30234-30238 (2015). https://doi. org/10.1039/C5RA03762J

Hazrat, M. A., Rasul, M. G., Khan, M. M. K. Lubricity improvement of the ultra-low sulfur diesel fuel with the biodiesel. Energy Procedia, 75, 111-117 (2015). https://doi.org/10.1016/j.egypro.2015.07.619

Hitam, C. N. C., Jalil, A. A., Triwahyono, S., Rahman, A. F. A., Hassan, N. S., Khusnun, N. F., Jamian, S. F., Mamat, C. R., Nabgan, W., Ahmad, A. Effect of carbon-interaction on structure-photoactivity of $\mathrm{Cu}$ doped amorphous $\mathrm{TiO}_{2}$ catalysts for visible-light-oriented oxidative desulfurization of dibenzothiophene. Fuel, 216, 407-417 (2018). https://doi.org/10.1016/j.fuel.2017.12.035

Ibrahim, M. H., Hayyan, M., Hashim, M. A., Hayyan, A. The role of ionic liquids in deseulfurization of fuels: A review. Renewable and Sustainable Energy Reviews, 76, 1534-1549 (2017). https:// doi.org/10.1016/j.rser.2016.11.194

Jha, D., Haider, Md. B., Kumar, R., Balathanigaimani, M.S.Extractive desulfurization of dibenzothiophene using phosphonium-based ionic liquid: Modeling of batch extraction experimental data and simulation of continuous extraction process. Chemical Engineering Research and Design, 111, 218-222 (2016). https://doi.org/10.1016/j. cherd.2016.05.006

Jiang, B., Yang, H., Zhang, L., Zhang, R., Sun, Y., Huang, Y. Efficient oxidative desulfurization of diesel fuel using amide-based ionic liquids. Chemical Engineering Journal, 283, 89-96 (2016). https://doi.org/10.1016/j.cej.2015.07.070

Julião, D., Valença, R., Ribeiro, J. C., Castro, B de, Balulua, S. S. Efficient eco-sustainable ionic liquid-polyoxometalate desulfurization processes for model and real diesel. Applied Catalysis A: General, 537, 93-99 (2017). https://doi. org/10.1016/j.apcata.2017.02.021

Kahani, S., Shafiei, M., Abdolmaleki, A., Karimi, $\mathrm{K}$. Enhancement of ethanol production by novel morpholinium ionic liquids. Journal of Cleaner Production, 168, 952-962 (2017). https://doi. org/10.1016/j.jclepro.2017.09.008 
Kaisy, G. M. J. Al, Mutalib, M. I. A., Bustam, M. A., Leveque, J., Muhammad, N. Liquid-Liquid extraction of aromatics and sulfur compounds from base oil using ionic liquids, Journal of Environmental Chemical Engineering, 4, 4786-4793 (2016). https://doi.org/10.1016/j.jece.2016.11.011

Lapuerta, M., Sànchez-Valdepeñas, J., Bolonio, D., Sukjit, E. Effect of fatty acid composition of methyl and ethyl esters on the lubricity at different humidities. Fuel, 184, 202-210 (2016). https://doi. org/10.1016/j.fuel.2016.07.019

Li, F., Wu B., Liu, R., Wang, X., Chen, L., Zhao, D. An inexpensive N-methyl-2-pyrrolidone-based ionic liquid as efficient extractant and catalyst for desulfurization of dibenzothiophene. Chemical Engineering Journal, 274, 192-199 (2015). https:// doi.org/10.1016/j.cej.2015.04.027

Li, H., Zhang, B., Jiang, W., Zhu, W., Zhang, M., Wang, C., Pang, J., Li, H. A comparative study of the extractive desulfurization mechanism by $\mathrm{Cu}(\mathrm{II})$ and $\mathrm{Zn}$-based imidazolium ionic liquids. Green Energy \& Environment, 4, 38-48 (2019). https:// doi.org/10.1016/j.gee.2017.10.003

Liu, X., Li, J., Wang, R. Desulfurization and regeneration performance of heteropoly compound/ ionic liquid solutions at high temperature. Chemical Engineering Journal, 316, 171-178 (2017). https:// doi.org/10.1016/j.cej.2017.01.093

Mafi, M., Dehghani, M. R., Mokhtarani, B., Liquidliquid equilibrium data for extractive desulfurization using 1-butyl-3-methyl imidazolium thiocyanate, n-alkane and thiophene. Fluid Phase Equilibria, 456, 109-115 (2018). https://doi.org/10.1016/j. fluid.2017.10.017

Martínez, I., Mohamed, M. El-Said, Santos, V. E., Garcia, J. L., García-Ochoa, F., Díaz, E. Metabolic and process engineering for biodesulfurization in Gram-negative bacteria. Journal of Biotechnology, 262, 47-55 (2017). https://doi.org/10.1016/j. jbiotec.2017.09.004

Mishra, S., Panda, S., Pradhan, N., Satapathy, D., Biswal, S., Mishra, B. K. Insights into DBT biodegradation by a native Rhodococcus strain and its sulfur removal efficacy for two Indian coals and calcined pet coke. International Biodeterioration \& Biodegradation, 120, 124-134 (2017). https://doi. org/10.1016/j.ibiod.2017.02.007

Moghadam, F. R., Azizian, S., Bayat, M., Yarie, M., Kianpour, E., Zolfigol, M. A. Extractive desulfurization of liquid fuel by using a green, neutral and task specific phosphonium ionic liquid with glyceryl moiety: A joint experimental and computational study. Fuel, 208, 214-222 (2017). https://doi.org/10.1016/j.fuel.2017.07.025

Mozafari, M., Nasri, Z. Operational conditions effects on Iranian heavy oil upgrading using microwave irradiation. Journal of Petroleum Science and Engineering, 151, 40-48 (2017). https://doi. org/10.1016/j.petrol.2017.01.028

Paixão, S. M., Arez, B. F., Roseiro, J. C., Alves, L. Simultaneously saccharification and fermentation approach as a tool for enhanced fossil fuels biodesulfurization. Journal of Environmental Management, 182, 397-405 (2016). https://doi. org/10.1016/j.jenvman.2016.07.099

Raj, J. J., Magaret, S., Pranesh, M., Lethesh, K. C., Devi, W. C., Mutalib, M. I. A. Extractive desulfurization of model fuel oil using ester functionalized imidazolium ionic liquids. Separation and Purification Technology, 196, 115-123 (2018). https://doi.org/10.1016/j.seppur.2017.08.050

Ren, Q., Zuo, T., Pan, J., Chen, C., Li, W. Preparation of Biodiesel from Soybean Catalysed by Basic Ionic Liquids [Hnmm]OH. Materials, 7, 8012-8023 (2014). https://doi.org/10.3390/ma7128012

Ren, T.-J., Zhang, J., Hu, Y.-H., Li, J.-P., Liu, M.S., Zhao, D.-S. Extractive desulfurization of fuel oil with metal-based ionic liquids. Chinese Chemical Letters, 26, 1169-1173 2015. https://doi. org/10.1016/j.cclet.2015.05.023

Rezvani, M.A., Khandan, S., Aghmasheh, M. Synthesis and characterization of new nanocomposite TBA-PW ${ }_{11} \mathrm{Ni@NiO} \mathrm{as} \mathrm{an} \mathrm{efficient} \mathrm{and} \mathrm{reusable}$ heterogeneous catalyst in oxidative desulfurization of gasoline. Journal of the Taiwan Institute of Chemical Engineers, 77, 321-328 (2017). https:// doi.org/10.1016/j.jtice.2017.05.014

Rodríguez-Cabo, B., Rodríguez, H., Rodil, E., Arce, A., Soto, A. Extractive and oxidative-extractive desulfurization of fuels with ionic liquids. Fuel, 117, 882-889 (2014). https://doi.org/10.1016/j. fuel.2013.10.012

Safa, M., Mokhtarani, B., Mortaheb, H. R. Deep extractive desulfurization of dibenzothiophene with imidazolium or pyridinium-based ionic liquids. Chemical Engineering Research and Design, 111, 323-331 (2016). https://doi.org/10.1016/j. cherd.2016.04.021

Shah, S. S., Ahmad, I., Ahmad, W. Adsorptive desulfurization study of liquid fuels using Tin (Sn) impregnated activated charcoal. Journal of Hazardous Materials, 304, 205-213 (2016). https:// doi.org/10.1016/j.jhazmat.2015.10.046

Taheri-Shakib, J., Shekarifard, A., Naderi, H. The experimental investigation of effect of microwave and ultrasonic waves on the key characteristics of heavy crude oil. Journal of Analytical and Applied Pyrolysis, 128, 92-101 (2017). https://doi. org/10.1016/j.jaap.2017.10.021

Vafaeezadeh, M., Alinezhad, H. Brønsted acidic ionic liquids: Green catalysts for essential organic reactions. Journal of Molecular Liquids, 
218，95-105 (2016). https://doi.org/10.1016/j. molliq.2016.02.017

Xu, H., Zhang, D., Wu, F., Cao, R. Deep oxidative desulfurization of fuels based on $\left.\mathrm{C}_{4} \mathrm{mimCl}\right]$ $\mathrm{CoCl}_{2}$ ionic liquid oxone solutions at room temperature. Fuel, 208, 508-513 (2017). https://doi. org/10.1016/j.fuel.2017.07.060

Yang, H., Bin, J., Sun, Y., Hao, L., Huang, Z., Zhang, L. Synthesis and oxidative desulfurization of novel lactam-based Brønsted-Lewis acidic ionic liquids. Chemical Engineering Journal, 306, 131-138 (2016). https://doi.org/10.1016/j.cej.2016.07.044

Yaun, P., Zhang, T. T., Cai, A. F., Cui, C. S., Liu, H. Y., Bao, X. J. Theoretical study on the mechanism of oxidative- extractive desulfurization in imidazoliumbased ionic liquid. RSC Advances, 6, 74929-74936 (2016). https://doi.org/10.1039/C6RA16731D

Yu, F., Liu, C., Yuan, B., Xie, P., Xie, C., Yu, S. Energyefficient extractive desulfurization of gasoline by polyether-based ionic liquids. Fuel, 177, 39-45 (2016). https://doi.org/10.1016/j.fuel.2016.02.063
Zaid, H. F. M., Kait, C. F., Mutalib, M. I. A. Extractive deep desulfurization of diesel using choline chloride-glycerol eutectic-based ionic liquid as green solvent. Fuel, 192, 10-17 (2017). https://doi. org/10.1016/j.fuel.2016.11.112

Zhang, L., Wang, J., Sun, Y., Jiang, B., Yang, H. Deep oxidative desulfurization of fuels by superbasederived Lewis acidic ionic liquids. Chemical Engineering Journal, 328, 445-453 (2017). https:// doi.org/10.1016/j.cej.2017.07.060

Zhao, H., Baker, G. A., Zhang, Q. Design rules of ionic liquids tasked for highly efficient fuel desulfurization by mild oxidative extraction. Fuel, 189, 334-339 (2017). https://doi.org/10.1016/j. fuel.2016.10.109

Zhao, H., Baker, G. A., Wagle, D. V., Ravula, S., Zhang, Q., Tuning task-specific ionic liquids for the extractive desulfurization of liquid fuel. ACS Sustainable Chemistry \& Engineering, 4, 4771-4780 (2016). https://doi.org/10.1021/ acssuschemeng.6b00972 
